\title{
An Integrated Approach to Early Childhood Education and Care and Integration within Education: The Brazilian Experience
}

\author{
Lenira Haddad \\ Center of Education, Federal University of Alagoas, Maceió, Brazil \\ Email: lenira.haddad@cedu.ufal.br
}

Received 31 December 2015; accepted 21 February 2016; published 26 February 2016

Copyright (C) 2016 by author and Scientific Research Publishing Inc.

This work is licensed under the Creative Commons Attribution International License (CC BY). http://creativecommons.org/licenses/by/4.0/

(c) (i) Open Access

\section{Abstract}

This paper aims at analyzing the premises that shape a model for an integrated approach to early childhood education and care and those that shape the integration of ECEC services within Education, considered here as two distinct movements. In previous study (Haddad, 2002), I defended the idea that wide world events such as the Cold War, the Western cultural revolution of the 1960s and 1970s and Globalization clearly influenced the adoption of a more or less integrated approach to ECCE. Now I shall argue that while an integrated approach to education and care is nourished by the ideals propagated by the counter-cultural revolution of the 60s, the integration within education is part of a globally structured agenda for education (Dale, 2000). The study is also oriented by the paradigm proposed by Cochran (1993) that policies and programs are a combination of causal factors and mediating influences, which components co-mingle and produce distinct combinations, which change over time. The main finding is that in the global structured agenda to education there is very small room for issues related to family life, gender equality and conciliation between work and family responsibilities. Basically, ECEC within education implies its legitimation as the first stage of basic education, and not as an integrated policy for ECEC.

\section{Keywords}

Early Childhood Education and Care, Integrated Approach, Integration within Education, Globalization

\section{Introduction}

The state management of childcare and preschool education has traditionally been separated into welfare and education, each having its own program funding and administrative arrangements. Such split systems have been 
the subject of critical discussion since the 1970s, with the debate towards an integrated approach to early childhood care and education (ECEC) intensifying following the work of the European Commission Network on Childcare in the 1980s and 1990s, and OECD thematic review on ECEC between 1998 and 2006. Some countries have sought mechanisms to overcome the inconsistencies of split systems by either setting up intersectoral coordination mechanisms or integrating the responsibilities for ECEC within a single sector.

This paper aims to explore the arguments for the two movements regarding integration: those towards shaping an integrated approach to childcare and preschool education in general, and those bringing those two areas within education. It will draw on my paper on an integrated approach to care and education (Haddad, 2002) ${ }^{1}$, and use the Brazilian experience, which officially integrated the responsibilities for ECEC into the Ministry of Education in 1996, to illustrate the discussion.

The paper is divided into three parts. The first one situates the two movements- the integrated approach to ECEC and the integration within education-in the context of the counter-cultural revolution of the 1960s and globalization. The second part explores the context of the expansion of ECEC services in Brazil before the reform of integrating ECEC within education. The final part analyses the reform in Brazil highlighting some main gains, losses, threats, and current challenges.

\section{Integrated Approach to ECEC and Integration within Education}

For Cochran (1993) childcare policies and programs are a combination of causal factors and mediating influences. His idea helps to understand that policies and programs components,-such as financing, target population, delivery, levels of access, age group, types of services, time of functioning, and staffing-co-mingle and produce distinct combinations, which change over time. This has several implications to the analyses of current policies of ECEC: first, programs components cannot be seen as static neither separated; second, each individual country produces ECEC policy and programs of particular type as a result of a unique combination of causal factors and mediating influences. Third, each particular childcare system must be understood from both perspectives, their own culture and in the "context of the macro-level forces that stimulate policy formation and the influences mediating how societal needs are translated into policy and programmatic form" (Cochran, 1993: p. 5). While causal factors and mediating influences shape particular systems, they are neither infinite nor have the same weight.

This section will draw on my previous study (Haddad, 2002) to explore the influence of world events such as the Cold War, the Western Cultural Revolution of the 1960s and 1970s and globalization on the adoption of a more or less integrated approach to ECEC. They raise new pressures, which create new value-based tensions for societies to solve, revealing what Cochran calls "pattern of change" once they transcend individual countries. I shall argue that while an integrated approach to early care and education was nourished by the counter-cultural revolution of the Sixties, integration within education was part of a globally structured agenda for education.

\subsection{An Integrated Approach to ECEC as an Expression of Counter Cultural Movements}

The call for an integrated approach to ECEC is a social phenomenon, a demand from civil society in most industrialized countries undergoing deep changes requiring new childcare arrangements. In many countries, the women's movement played an important role in creating new possibilities for extra parental child socialization, opening up a new concept of childcare-with professional and educational components, which met the child's needs for care and education as well as the social, occupational and family needs of women. This new conceptual framework, encompassing the social and educational dimensions, could be seen as one of the seeds sown in the development of what is now called ECEC (Haddad, 2002: p. 22).

Childcare began to move out of the domestic arena and become considered as an important social means for promoting human development to be guaranteed by public authorities. The work carried out by the EC Network on Child Care (1986-1996) and the OECD review (1998 and 2006) contributed to this debate.

Established in 1988 and committed to gender equality, the EC Network on Childcare encompassed a wide range of issues correlated to ECEC services such as parental employment, parental leave, men as carers and childcare in rural areas. The Network's concept of "child care" was broad and included the need for employment and the upbringing of children to be combined in a way that promoted gender equality, the best use of parents'

\footnotetext{
${ }^{1}$ The paper was commissioned by OECD and UNESCO on the launching of Starting Strong I (OECD, 2001) at the International Conference in Stockholm hosted by the Swedish Ministry of Education and Sciences.
} 
skills and abilities and the well-being and development of children (EC Childcare Network, 1992: p. 6).

The majority of the members states' provision came under the responsibility of two systems: welfare and education. Lack of coherence and inconsistencies between the services offered led to uncoordinated services and overlap of public responsibilities as well as affecting funding systems and admission criteria. Publicly funded services for children under 3 , which were often dealt with within the welfare system, were low in terms of supply and offered a lower level of skilled professionals, work, and pay conditions, when compared to the services for children over 3 . The latter, generally linked to the educational sector, offered greater availability but with shorter opening hours.

The 1996 EC Childcare Network report took another important step forward towards integration. It focused on the volume of services offered arguing that critical dimension could not be reached by simply counting the number of children and places available in each establishment. Greater availability, daily and annually, as found in the services linked to the welfare systems, was recognized as more in tune with the needs of families and working parents compared to those linked to the education systems. The report was critical of the failure of the education system to take into account the needs of working parents and care for school age children. The 1996 Report concluded by calling for "a holistic approach to the needs of children and their families" (EC Childcare Network, 1996: p. 135).

Several of the premises established by the EC Network on Childcare remained as references in the OECD thematic review launched in 1998. The adoption of the terminology Early Childhood Education and Care (ECEC) was a deliberate option to emphasize the fact that "care" and "education" are inseparable. The review supports "an integrated and coherent approach to policy and provision which is inclusive of all children and all parents, regardless of their employment or socio-economic status” (OECD, 2001: p. 14). Therefore, OECD’S Starting Strong program assumes an inclusive approach towards human rights with implications for policy and program implementation. First, children are seen as a "social group with rights, and not just as dependents on parents or as primarily in need of childcare to enable their parents' employment” (p. 127). Second, ECEC policies are considered "part of a system of wider support to promote the well-being of children and families" (p. 34). Great consideration is given to the potential of ECEC to support parents in conciliating work and family responsibility as well to promote gender equality. This approach emphasizes the close link between ECEC and parental leave policies as well as the socialization of children in both rural and urban areas. The broader role of ECEC is defined as a "place for children in their early years to socialize and learn through their relationships with other children and other adults" (p. 41). The review acknowledges that it is important for children to possess skills and learning strategies for school but is critical of the view that they need to be prepared for school and the future.

The second comparative report on the thematic review on ECEC (OECD, 2006) reviews the challenges of ECEC policy-making and service coordination, and restates the broader ECEC policy view that concerned not only with providing education and care to young children, but also with women's and children's rights. The report indicates that integration under one ministry brings a clearer policy vision in ECEC and more effective funding and management of the system.

Neuman (2005: pp. 134-135) calls attention to important political and philosophical issues raised by the decision to integrate all early childhood services into the national education system. One concern about bringing together some areas of responsibility is the marginalization of child welfare, health and other services from ECEC, making coordination with such services more challenging, and the exacerbation of coordination barriers with non- education sectors. Another concern is related to the loss of early childhood traditions and practices to a dominant schooling model focused on a narrower set of academic concerns and the erosion of specific pedagogical pre-school methods. While institutional positioning of ECEC within the education system may strengthen its political status with regards to national policy, it may lose some specificity vis-à-vis primary education and policy may become less distinctive.

These concerns are embodied in the term "schoolification" to express what can happen when early education adopts the knowledge transfer model of primary education and is conceived of as a "junior school". The term encompasses a combination of classes organized according to age; adoption of contents and methods of primary schooling with stress on literacy and numeracy; scheduled activities planned mostly indoors; little time left for free play, choice of activities and outdoor discoveries. In this model, teachers are trained predominantly in primary education methods and have little or no certification in early childhood pedagogy (OECD, 2006: p. 62). 
According to Kaga et al. (2010), there are conflicting arguments and ambivalent feelings about integrating ECEC services in education but relatively little information on its consequences. The lack of comparative research assessing this option motivated the launching of UNESCO's Caring and Learning Together project ${ }^{2}$ that investigates nine countries' experiences with different types of governance.

\subsection{Integration within Education as an Expression of Globalization}

Integration within education has evolved from being an expression of civil society movements to become a government trend towards consolidating a national ECEC policy under the aegis of the ministry of education as part of the schooling system and within the context of globalization. Dale (2000: p. 436) explores the relation between globalization and education, in his approach named "Globally Structured Agenda for Education”. In this approach, globalization is seen as being constructed through three related sets of activities: economic, political, and cultural, which "may be characterized as hyper-liberalism, governance without government, and commodification and consumerism, respectively".

In effect, this new form of globalization means that national regulatory policy is molded, to a certain extent, by both supranational and national political-economic forces. Today the EU, the OECD, the World Trade Organization (WTO) and the World Bank (WB) are key players in the educational agenda (Antunes, 2005). With different degrees of influence and importance, these organizations have direct intervention in educational policies. This external influence was highlighted at the World Education for All (EFA) Conference held in Jomtien in 1990, since EFA served as a landmark for designing educational policies worldwide, especially in basic education (Fullgraf, 2007).

However, beyond the focus limited to only education, this original broad vision of basic education i.e. basic learning skills for the world's population and the ambitious goal of a quality education for all has narrowed in many senses (Torres, 2001). Learning identified with school performance gave rise to standardized tests; 'the traditional confusion between education and teaching, as well as between teaching and learning, suggested that "improving education" is equivalent to "improving teaching" and that both "improve learning" and the emphasis on contents and results rather than processes, resulting in the adoption of assessment systems by most countries (Torres, 2001: pp. 44-45).

The trend the 90s that "bet on increasing the time (of study, schooling, exposure to teaching) as a key variable to improve learning" illustrates the impact of that concept of learning (Torres, 2001: p. 48). In this decade, most countries in Latin America, the Caribbean, Africa and Asia increased the number of years of compulsory education to eight, nine, ten, eleven or more. In many cases, this increase meant the inclusion of one or two years of pre-school education. These changes in the broad concept of basic education directly influenced the identity and goals of early childhood education in the sense that "the programs are being promoted not so much as a function of child development, but as 'preventive strategy of school failure' among the most 'needy”' (Torres, 2001: p. 35).

The first goal adopted by EFA, 'Expanding and improving comprehensive early childhood care and education, especially for the most vulnerable and disadvantaged children', involves a realignment of ECEC policies in developing countries. As found in the previous study (Haddad, 2002), two sets of priorities to achieve this goal were observed, which differ according to age group. One refers to the expansion of preschool classes for the age that precedes compulsory schooling, with a view to universalizing admission to ages $4-5$, as a way of guaranteeing full access to formal schooling. The second refers to programs for families and communities directed at children under 3. Of note was the adoption of different terminologies by international organizations (such as Early Childhood Development-ECD-used by WB and UNICEF), which have 'undermined the concept of social responsibility, and accentuated the gap between developed and developing countries.

In contrast to the EC Network on Childcare and OECD's Starting Strong program, the literature of international organizations such as UNICEF and WB regarding developing countries advocates that "programs should be less costly and run by mothers or community leaders"; "parents and close caregivers (such as older siblings) should be an equal target population"; "settings should be community or home-based"; and "private sector involvement should be encouraged” ( $c f$ Haddad, 2002: p. 41).

\footnotetext{
${ }^{2}$ The project Learning and Caring Together (Kaga, Bennett \& Moss, 2010) identifies 15 countries where ECEC is integrated within education: Iceland, New Zealand (1986), Viet Nam (1986), Spain (1990), Botswana (1994), Brazil, Slovenia, Sweden (1996), England, Jamaica, Scotland (1998), and Norway (2005).
} 
Closely examining OECD’s ECEC policy discourses and those of the WB, Mahon (2011) found similar trends. While the WB and its networks draw their inspiration from the residual American social policy model, targeting the poor while leaving the rest to rely on markets and families, Starting Strong reflects European social policy and especially the Nordic model, which embodies the principle of universality. There are huge differences too in the approach to women. The WB remains rooted in American family values and emphasizes women's maternal role, while the OECD and the EU remain committed to "women's equality with men in the labor market and the importance of shared parental leave” (Mahon, 2011: p. 92).

\section{The Context of the Expansion of ECEC in Brazil}

This section discusses the context in which the expansion of ECEC took place in Brazil and the two contrasting waves of expansion prior to crèches and preschools being acknowledged as part of children's right to education in 1988. The first, named mass model, was adopted by the military government during the regime of dictatorship. The second took place in the transition to democracy and was strongly driven by civil society movements.

Models for a mass ECEC program were introduced in Brazil in the early 70s, based on proposals from international organizations, such as UNICEF and UNESCO (Rosemberg, 1997, 2002, 2006). Cultural deprivation theories developed in the US during the 1960s also had a strong impact. Consequently, ECEC began to be fostered as compensatory education. Alternative preschool as a model that "fuses community participation with low-cost solutions" was the answer found by the Brazilian federal government to make expansionist goals compatible with the scarcity of public funds (Campos, 1992: p. 487). The implementation of this type of mass program for young children began in 1974 with ProjetoCasulo (Cocoon Project), a Brazilian Legion of Assistance (LBA) project linked to the welfare system, and later through MOBRAL (Brazilian Literacy Movement), linked to the Ministry of Education (MEC).

These two projects characterized the institutionalization of ECEC as a non-formal model, supported by volunteer work or underpaid lay teachers, and targeted at the poorest regions of the country. However, importing the low-cost model to Brazil brought with it gender inequality, as well as race and class exclusion (ROSEMBERG, 2006). Moreover,

In basing itself on the principle of women's hidden ability to be child caretakers and educators, the low-cost model employed women who had a very particular repertory for what ECEC would be. The model available to them was the school they had known as children, which many of them had abandoned. Brazilian ECEC came to be, in many cases, an anticipation of obligatory schooling, even proposing to teach children literacy in addition to keeping them in a protected space for a certain period. (Rosemberg, 2006: p. 78)

The second wave of expansion begun almost at the same time, as a response to a legitimate demand created by social movements. The 1970s brought a revolution in thinking on social and individual rights, signaling the transition to democracy. Social movements fighting for better living and working conditions sprang up all over the country. In São Paulo, politicized working-class women began to fight for better transportation, health centers, schools, and a place to leave their children while they went to work. Feminist groups strengthened the demand for crèches and the traditional vision of childcare in Brazil underwent a fundamental change. Feminists viewed childcare as a "fundamental part of the collective services that should be made available for women and men, in the context of a society that would not discriminate against women”. In addition, these services should be provided by public institutions (Campos, 1992: p. 500). The call for crèches $^{3}$ became a public demand at the first Women's Congress held in São Paulo in March 1979 and let to the launch of the Movement Fighting for Crèches (Movimento de Luta por Creches-MLC) in the same year.

Women's Councils functioned as a mediator between the state and women's movements. The National Council on Women's Rights (Conselho Nacional dos Direitos da Mulher-CNDM), created in 1985, formed a committee to draw up a childcare proposal for the new constitution, in which crèche was to be considered as "an extension of the universal right to education of the citizen-child in the age range from 0 to 6 years”.

The proposal included administrative support, an integrated national policy taking into account regional differences, a legal definition of administrative competency and financial support, and acknowledgement of caretakers as professionals. It also emphasized the need to consider the rights of both children and women in the im-

\footnotetext{
${ }^{3}$ The option for the word crèche instead of day care center, in this paper is due to this is the word officially adopted by the social movements and the Movement Fighting for Crèche that became official in 1979. During the first wave of expansion, crèche and preschool were used indiscriminately. However, in the second wave crèche was the slogan. The Ministry of Education, where the preschools were linked, remained neutral. Crèche was included in the Constitution of 1979 as a result of this Movement.
} 
plementation of any policy (Rosemberg, 1993: p. 53).

Many members of the MLC were recruited to work in the new public day care centers, bringing with them a new political and professional stance. In São Paulo, the government engineered a real breakthrough by hiring directors of university level for the centers.

Last but not least, it is important to mention the qualitative leap made in research on ECEC from the 1980s. Up until the 1970s, studies on day care centers focused on the effects of maternal deprivation on the development of children, and research on preschool tended to concentrate on development of strategies to avoid cultural deprivation and future school failure. By that time, day care establishments for the first time became legitimate sources of data collection. A wave of researches that followed brought new themes unexplored before such as the status of woman, maternity, paternity, the role of the professional, the pedagogical dimension, the family and institution relationship, and the role of the state (Campos \& Haddad, 1992).

All these factors resulted in crèches and preschool becoming enshrined in the Brazilian Constitution of 1988. Two articles guaranteed the rights of children and their families: Admission to day care and preschools for children from zero to six was recognized as an educational right and responsibility of the state (Art. 208) and all children of working parents (urban and rural) were to be granted free attendance in day care and preschools (Art.7, XXV). Thus, the Brazilian Constitution acknowledged ECEC as both a right to education and as a mechanism to support gender equality. However, in practice the last article, related to the working parents although included in the constitution has never been implemented.

Between 1988 and 1996 prior to the Law of Guidelines and Bases of National Education (LDB), two sets of initiatives were taken, one at the policy level, with the MEC working on the constitutional perspective, and the other at the level of program implementation by municipalities.

At the local level, especially within the state of São Paulo, several municipalities moved ahead of the law and integrated day care and preschools within education. I worked as consultant to the Secretary of Education in Ubatuba, state of São Paulo, during the 1993-96 administration. The municipality created a new type of institution, the ECE Integrated Municipal Unit (UNIMEI), for children aged 0 to 6, both part time and full time. The units were seen as the basis for a new approach to ECEC for the entire city. This process was supported by training and interventions strategies, which also included exchanges with Italy and Denmark (Haddad, 1996).

With the change of local government in 1996, which coincided with the approving of LDB, these integrated units were considered unconstitutional-since the law states that crèche exists for children aged $0-3$ and pre-school for 4 - 6- and were dismantled. Shortly after, with the municipalization of primary education, children of compulsory school age occupied classrooms intended for children aged 0 to 3 . The dismantling of the successful experience of Ubatuba also reflects national and international political and economic with resources channeled primarily to primary education.

Here we see one of the consequences of the maintenance of old terminologies instead of using new ones. It was thought that, by differentiating these types of institutions by age the traditional division peculiar to the split system (full-time day care centers for poor families and part-time preschool for four- to six-year-olds) would be eliminated (Rosemberg, 1993). However, it gave space not only to varying interpretations but also to political manipulation due to new priorities in the economic agenda. For example, in many cities in Brazil, the transfer of services to the educational sector has brought about a reduction in full-time coverage for four- to six- year-old children attending day-care centers, neglect of the need for provision for the under-threes and the elimination of the four- to six-year-old children from the day care centers.

\section{Integration within Education ${ }^{4}$ and the Consequences for ECEC as a Unified System}

The approval of LDB in 1996 came at a time of new world economic order marked by the restriction of the state role in social policies and a reduction in public investment. This new order affected education, as well as women's rights. Among the actors linked to achievements in ECEC is the National Council on Women's Rights, which ended up losing the budget and representative support from the Ministry of Justice.

The first decade after the approval of LDB was marked by the absence of a national ECEC policy for implementation of the reform. The main reason is attributed to the partnership of the neo-liberal stance of the gov-

${ }^{4}$ For a discussion on the Brazilian rationales and process of integration within education, refer to Nunes et al. (2010) within the framework of UNESCO’s Caring and Learning Together project. 
ernment elected in 1994 with the WB. Two complementary factors of the WB are considered to have influenced ECEC policy: general reform with public investment in elementary education made a priority, and the return of non-formal programs for poor children, especially the under threes, such as the Early Childhood Development programs by means of low public investment (Rosemberg, 2002).

In line with this policy, the first funding program after LDB (FUNDEF) was approved in 1997 and gave priority to primary education, forcing ECEC to compete with other educational expenses for municipal resources. The new educational funding (FUNDEB), which included all levels of basic education, took a long time to be approved by the National Congress. In its first version (2005), the education of 0 to 3 year olds was excluded from the fund due to strong resistance from federal and local governments to the expansion of resources for ECEC.

A long and intense process of negotiation, involving mobilization from civil organizations fighting for the right to the unity of ECEC, reversed this situation (Nunes et al., 2010). In January 2007, with the approval of FUNDEB, all enrolments in crèche and pre-school at the municipal level, including private services provided by non-profit institutions through previous agreements, qualified for a "yearly amount per student". However, FUNDEB still failed concerning distribution among the regions and funds for full time provision.

Meanwhile, a large amount of funding for ECEC remained in the Ministry of Social Development (MDS) without an easy means of transfer to the education system. Finally, with the approval of FUNDEB in 2007, all ECEC services funded by the welfare sector were transferred to education.

There is much evidence to show the development of a globally structured agenda for education throughout the consolidation of a national ECEC policy. Particularly relevant is the strengthening of schooling for 4 to 5 year olds and the downgrading of collective education for children under 3. For Fulgraff (2007), it is all about forcing the separation of 0 - 3 year olds from the logic of basic education and inserting it in the logic of protection and support of early childhood development (ECD), following UNICEF and WB. In other words, it implies not supporting the legitimacy of 0 - 3 year olds as part of basic education as it is defined in the LDB.

Two recent changes in the organization of basic education have substantially affected the identity of ECEC in Brazil. The first, approved in 2006, extended the period of compulsory schooling from 8 to 9 years by the inclusion of all 6-year-old children in elementary education nationwide. As a result, the age range of ECEC decreased to 0 to 5 .

The second, approved in 2009, extended the period of compulsory basic education from the age of 4 . Thus, basic education becomes compulsory and free for ages 4 to 17, and should be implemented until 2016. The latter change came as a shock. Although the right to a place in preschool had been guaranteed in the 1998 Constitution, enrolment in day care center and preschool had thus far been a family choice. Mandatory enrolment was seen by some as a challenge to the autonomy and freedom of citizens. By making participation in ECEC obligatory for 4 - 5 years olds, the movements toward deeper integration of the crèche and preschool sectors initiated in 1996 may be hindered, and the old 'care/education' divide may become accentuated within the administratively integrated system. It was also feared that the expansion of educational provision for pre-school would penalize access for children under 3 , since the coverage for this age group is still low (only 23.6 per cent for day care comparing to 80.1 per cent in preschool in 2010).

Reducing the social dimensions of ECEC can be seen as a failure to address the need of working parents for full-time provision. A decrease in full-time coverage for children aged 4 - 6 attending ECEC programs was observed since 1996, when LDB redefined the terms crèche and preschool by age. Although the previous National Plan for Education (PNE 2000-2010) had fixed the gradual adoption of full-time attendance for children aged 0 5 , in practice it has not reached preschool. In 2009, the proportion of full-time enrolments was 64.6 per cent for crèche and only 7.7 per cent for preschool (Brazil, 2009).

It is interesting to note that the need for full time provision is invariably associated with crèche and not with preschool, i.e. it is not associated with ECEC as a whole. This reflects the resistance of the educational sector to accept a full day program that goes beyond teaching activities.

In fact, in the globally structured educational agenda there is little room for issues related to family life, gender equality and reconciliation between work and family responsibilities. As Mahon states (2011: p. 81), gender equity in the ECEC discourse of the WB is less 'a matter of equality between men and women than as means for levelling the playing field between boys and girls with regard to access to education'. The implication for policy and practice is a conceptual reduction of early childhood education and care; in the education system, ECEC is- 
legitimized onlyas the first stage of basic education, and not as an integrated policy, that combines education and social dimensions.

From the lens of an integrated approach, the transference of ECEC services to education in Brazil has meant the subordination of the social dimensions, especially what concerns gender. The resistance to put in force the Brazilian Constitution article that guarantees the right of workers (men and women, rural and urban) to having their children enrolled in day care and pre-schools can be seen as a symptom.

In an interview for this paper, MEC's general coordinator for ECEC, Rita Coelho, said: in the process of construction of a national policy for ECEC, workers' rights have never been on the agenda of the MEC or the Brazilian ECE Inter-forum Movement (MIEIB) or by sectors linked to the labor and employment. Lack of tradition of intersectoraldialog of Education with these other actors on such a comprehensive dimension explains this omission. For her, the intense struggle (after approval of the LDB in 1996) was for the acknowledgment of ECEC identity and educational role. The consequence was the educational system as a place for ECEC, at federal and local level. Moreover, she states that

When the crèches came to be part of Education, it entered a system that had already got its identity, which is powerful and has its own rules. [...] Crèche and the smallest children are rejected by Education. Education does not identify itself with the daily routine of small children, with the culture of children in the sense of playfulness and flexibility. We entered a ready system and there is not a movement on the part of Education to adjust the system to ECEC. On the contrary, it is ECEC that has to adapt itself to the system. [...] ECEC entries sort of in the place of this oppressed childhood, subordinate in a society ruled by adultcentrism that discriminates the babies (Interview with Rita Coelho, 2013).

Coelho believes the education system remains hegemonistic, jeopardizing and impoverishing ECEC. The present model does not meet the needs of ECEC, such as holidays, teachers' workload; special policies for infants and toddlers, and the needs of rural families. Notwithstanding, the interviewee believes that the transference of all ECEC institutions to Education was an extraordinary move for Brazil, given advances in major indicators such as funding, teacher training, enrolments, network expansion and monitoring, to mention a few. "If the services remained within the welfare ECEC they could not be claimed as an education policy”.

\section{Conclusions}

As far as the integrate approach goes and in relation to international developments, Brazil has taken a middle way. It has not opted for the integration of social and educational dimensions to establish commitments that extend beyond the rights of the child to those involving parents' work, parental leave and gender equality, as proposed by the European Union and OECD. Neither has it opted for an approach promoted by the World Bank whereby the government effort targets the poor and the private provision is expected to cater to the rest of the population.

The political option to integrate all ECEC services within the education system follows the "principle of integrating the institutions in the education systems to work on educational features under the coordination of Education" (Nunes et al., 2010: p. 33).

This means integration at several operational levels and with regard to local policies, which is an endless endeavor considering the size and complexity of the country and its educational system. Overall, integration has meant the consolidation of a national ECEC policy for regulation, provision, funding, monitoring, and professionalization. Being placed within the education system has involved adjustments to its structure and functioning mainly in terms of formal settings, which prevents the incorporation of alternative or non-formal arrangements, as in some other countries.

Thus, there is no doubt that the major consequence of the integration of ECEC within education has been the consolidation of pathways for policy implementation. However, many challenges remain to be overcome, the greatest, perhaps, is being the recognition of ECEC as unique and distinct from elementary school, with its mixture of social and educational elements and the overriding goal of fostering education in its broadest sense.

\section{Acknowledgements}

This paper received financial support by UNESCO. I thank Yoshie Kaga for the motivation, exchanging of ideas and documents and the valuable comments and contributions to it. 


\section{References}

Antunes, F. (2005). Governação global e diretrizesinternacionais paraeducaçãonaUniãoEuropéia (Global Governance and International Guidelines for Education in the European Union). Perspectiva, 23, 449-465.

Brazil. Inep. (2009). Institutonacional de estudos e pesquisaseducacionais. Resumotécnico do censo da educaçãobásica (Technical Summary of Basic Education Census). http://portal.inep.gov.br/resumos-tecnicos

Campos, M. M. (1992). “Child care in Brazil”. In M. E. Lamb et al. (Eds.), Child Care in Context: Cross-Cultural Perspectives (pp. 479-508). London: Lawrence Erlbaum Associates.

Campos, M. M., \& Haddad, L. (1992). Educaçãoinfantil: crescendo e aparecendo (Early Childhood Education: Growing and Appearing). Cadernos de pesquisa, No. 80, 11-20.

Cochran, M. (1993). International Handbook of Child Care Policies and Programs. Westport, CT: Greenwood Press.

Dale, R. (2000). Globalization and Education: Demonstrating a “Common World Educational Culture” or Locating a "Globally Structured Educational Agenda”? Educational Theory, 50, 427-448.

EC Childcare Network. (1992). Childcare and Equality of Opportunity: Consolidated Report of the European Commission. Brussels: European Commission Equal Opportunities Unit.

EC Childcare Network. (1996). Quality Targets in Services for Young Children. Brussels: European Commission Equal Opportunities Unit.

Fullgraf, J. (2007). O UNICEF e a política de educaçãoinfantil no governolula (UNICEF and the ECE Policy of Lula’s Government). Doctoral Thesis, São Paulo: Pontifícia Universidade Católica de São Paulo.

Haddad, L. (2002). An Integrated Approach to Early Childhood Education and Care. Early Childhood and Family Policy Series No. 3. Paris: UNESCO.

Haddad, L. (1996). Rumo a uma política integrada de educação infantil: A experiência do município de Ubatuba, Brasil (Towards an Integrated ECE Policy: The Experience of the Municipality of Ubatuba). 6th European Conference on the Quality of Early Childhood Education, Lisbon, 1-4 September 1996, 46-47.

Kaga, Y., Bennett, J., \& Moss, P. (2010). Caring and Learning Together: A Cross-National Study of Integration of Early Childhood Care and Education within Education. Paris: UNESCO.

Mahon, R. (2011). Transnationalizing (Child) Care Policy: The OECD and the World Bank. In R. Mahon, \& F. Robinson (Eds.), Feminist Ethics and Social Policy: Towards a New Global Political Economy of Care (pp. 77-93). Vancouver: University of British Columbia Press.

Neuman, M. J. (2005). Governance of Early Childhood Care and Education: Recent Developments in OECD Countries. Early Years, 25, 129-141. http://dx.doi.org/10.1080/09575140500130992

Nunes, M. F., Corsino, P., \& Didonet, V. (2010). Caring and Learning Together: A Case Study of Brazil. Paris: UNESCO.

OECD (2001). Starting Strong: Early Childhood Education and Care. Paris: OECD.

OECD (2006). Starting Strong II: Early Childhood Education and Care. Paris: OECD.

Rosemberg, F. (1997). A LBA, o projetocasulo e a doutrina de segurançanacional (Cocoon Project and the National Security Doctrine). In M. Freitas (Ed.), História social da infância no brasil (pp. 137-159). São Paulo: Cortez.

Rosemberg, F. (2002). Organizações multilaterais, estado e políticas de educação infantil (Multilateral Organizations, State and Early Childhood Education Policies). Cadernos de Pesquisa, No. 115, 25-63.

Rosemberg, F. (2006). Multilateral Organizations and Early Child Care and Education Policies for Developing Countries. In M. K. Zimmerman, J. S. Litt, \& C. E. Bose (Eds.), Global Dimensions of Gender and Carework (pp. 75-85). Stanford, CA: Stanford University Press.

Rosemberg, F. (1993). Brazil. In M. Cochran (Ed.), The International Handbook of Child Care Policies and Programs (pp. 627-658). Westport, CT: Greenwood Press.

Torres, R. M. (2001). Educação para todos: A tarefa por fazer (Education for All: A Task to Be Done). Porto Alegre: Artmed. 